\title{
PENTINGNYA PENILAIAN POTENSI DIRI WIRAUSAHA SEBAGAI PONDASI UNTUK MENSUKSESKAN PROGRAM MAHASISWA WIRAUSAHA (PMW)
}

\author{
Kadek Rai Suwena \\ Jurusan Pendidikan Ekonomi \\ Universitas Pendidikan Ganesha \\ Singaraja, Indonesia \\ E-mail:kadek_suwena@yahoo.co.id
}

\begin{abstract}
Abstrak
Sebagai usaha dalam menumbuhkembangkan jiwa kewirausahaan dan meningkatkan aktivitas kewirausahaan agar para lulusan perguruan tinggi lebih menjadi pencipta lapangan kerja dikembangkan Program Mahasiswa Wirausaha (PMW), sebagai bagian dari strategi pendidikan kewirausahaan di Perguruan Tinggi. Hanya saja, jarang ditemukan seorang sarjana yang ingin mengawali kehidupannya setelah lulus dari perguruan tinggi dengan berwirausaha. Kegagalan dari usaha tersebut diduga dikarenakan sikap yang kurang sungguh-sungguh dalam berusaha dan mengenali potensi diri yang ada dalam diri mahasiswa. Mengenali potensi diri wirausaha mahasiswa dapat dinilai dari enam aspek, yaitu: kepribadian, disiplin diri, kreativitas, dorongan/keinginan, keberanian menghadapi risiko, dan kepercayaan diri. Sedikit tidaknya dengan mengenali potensi diri yang ada dalam diri mahasiswa dapat memberikan gambaran tentang seberapa jauh seseorang tersebut merasa dirinya perlu memperbaiki diri dan belajar agar lebih baik lagi. Mengenal diri sendiri berarti memperoleh pengetahuan tentang totalitas diri yang tepat, yaitu menyadari kelebihan/keunggulan yang dimiliki maupun kekurangan/ kelemahan yang ada pada diri sendiri yang nantinya menjadi sumber kesuksesan dalam berwirausaha.
\end{abstract}

Kata Kunci: Potensi Diri, Kewirausahaan

\begin{abstract}
Student Entrepreneurship Program (PMW) is developed as a part of educational entrepreneurship strategy in university in order to be an effort to foster the entrepreneurial spirit and increase entrepreneurial activity in order to make graduates of college be job creators. However, it's just rare to find a scholar who wants to start his life after graduating from college as entrepreneurship. The failure of these efforts due to unserious attitude in doing an effort and do not recognize the potential that exists within the scholars themselves. Knowing the student entrepreneurship potential can be assessed from six aspects: personality, selfdiscipline, creativity, impulse/desire, the courage to face risks, and confidence. At least by recognizing the potential that exists within the student can give an idea of
\end{abstract}


how far someone felt he needed to improve themselves and learn to be better. Knowing yourself means you acquire knowledge about the proper totality of yourself, you realize your strength/talent and weaknesses/vulnerability in yourself that would be a source of success in entrepreneurship later.

Keywords: Self Potential, Entrepreneurship

\section{PENDAHULUAN}

$\begin{array}{ccr}\text { Badan } & \text { Pusat } & \text { Statistik } \\ \text { menyebutkan } & \text { bahwa } & \text { tingkat }\end{array}$ pengangguran terbuka di Indonesia pada tahun 2014 mencapai $6,25 \%$ atau 7,9 juta dan jumlah lulusan perguruan tinggi sebanyak 688.660 orang (495.143 Sarjana dan 193.517 Diploma). Setiap tahun pengangguran ini tetap menjadi permasalahan yang harus dicarikan penyelesaiannya. Keterbatasan terserapnya lulusan perguruan tinggi di sektor pemerintah menyebabkan perhatian beralih pada peluang bekerja pada sektor swasta, namun beratnya persyaratan yang ditetapkan terkadang membuat peluang untuk bekerja di sektor swasta juga semakin terbatas. Satu-satunya peluang yang masih sangat besar adalah bekerja dengan memulai usaha mandiri berupa berwirausaha.

Sebagai usaha

dalam menumbuhkembangkan jiwa kewirausahaan dan meningkatkan aktivitas kewirausahaan agar para lulusan perguruan tinggi lebih menjadi pencipta lapangan kerja, Kementerian Pendidikan dan Kebudayaan telah mengembangkan berbagai kebijakan dan program. Sejak tahun 1998 salah satu program yang telah dikembangkan adalah Program Kreatifitas Mahasiswa (PKM) Kewirausahaan dan Co-op (Cooperative Education Program), dengan tujuan untuk membentuk wirausaha melalui pendidikan tinggi.
Mulai tahun 2003 dikembangkan program Co-op yang memberikan kesempatan belajar bekerja secara terpadu pada Unit Kegiatan Mahasiswa (UKM). Agar program kewirausahaan dapat berjalan secara berkesinambungan di perguruan tinggi serta mempunyai sistem pengelolaan yang terencana dengan sistematis dan progresif, di masing-masing perguruan tinggi harus terus meningkatkan peran lembaga khusus pengembangan pusat kewirausahaan serta produktivitas nasional. Lembaga ini diharapkan secara sistematis dapat mengubah dan atau memperbaiki kualitas sistem pendidikan atau pembelajaran yang ada sehingga mahasiswa tidak hanya memiliki pengetahuan dan keahlian di dalam ilmunya, tetapi juga mampu memanfaatkan dan mengolah ilmunya bagi peningkatan nilai sumber daya yang tersedia di masyarakat bagi kesejahteraannya sendiri maupun kesejahteraan masyarakat dan bangsa.

Kebijakan dan program peningkatan peran yang mendorong penguatan kelembagaan kewirausahaan dalam meningkatkan kualitas pembelajaran dan aktivitas berwirausaha dan percepatan pertumbuhan wirausaha-wirausaha baru dengan basis Ipteks sangat diperlukan. Atas dasar pemikiran tersebut Direktorat Jenderal Pendidikan Tinggi mengembangkan Program Mahasiswa Wirausaha (PMW). PMW 
sebagai bagian dari strategi pendidikan kewirausahaan di perguruan tinggi, dimaksudkan untuk memfasilitasi para mahasiswa yang mempunyai minat berwirausaha dan memulai usaha dengan basis ilmu pengetahuan, teknologi, dan seni. Fasilitas yang diberikan meliputi pendidikan dan pelatihan kewirausahaan, magang, penyusunan rencana bisnis, dukungan permodalan dan pendampingan serta keberlanjutan usaha. Program ini diharapkan mampu mendukung visi-misi pemerintah dalam mewujudkan kemandirian bangsa melalui penciptaan lapangan kerja dan pemberdayaan. Dalam rangka mengembangkan diri sebagai seorang wirausahawan yang potensial, kita perlu mengenali siapa diri kita sebenarnya.

Mengenal potensi diri dalam rangka mengembangkan diri sebagai seorang wirausahawan yang potensial, kita perlu mengenali siapa diri kita sebenarnya dan bagaimana orang lain menilai diri kita (Suryana, 2011). Untuk menilai diri sendiri, proses awal adalah kita harus mengetahui kelemahan yang ada dalam diri kita dan memperbaikinya, yang kedua adalah mengenali potensi apa yang terdapat dalam diri kita yang selanjutnya kita ubah menjadi sebuah kompetensi yang dibungkus dengan atitude yang baik, kemudian kita bisa meraih apa yang kita inginkan (kesuksesan). Banyak orang mengartikan kesuksesan itu dengan ukuran materi. Namun, kesuksesan yang sebenarnya adalah kemampuan diri kita untuk mengenali potensi yang terdapat dalam diri kita sendiri dan memaksimalkannya menjadi sebuah kompetensi, dan kompetensi tersebut digunakan untuk meraih sesuatu yang lebih baik. Jika potensi yang ada dalam diri kita adalah menjadi seorang pengusaha maka kita harus memaksimalkan potensi kita tersebut.

Universitas Pendidikan Ganesha (Undiksha) sebagai salah satu universitas yang juga melaksanakan PMW tersebut sejak tahun 2009. Program tersebut mampu menarik minat mahasiswa untuk berwirausaha namun ketertarikan mahasiswa untuk mengikuti program PMW tersebut tidak diiringi oleh keberhasilan. Kenyataan itu ditunjukkan dengan data yang ada, dimana pada tahun 2010 hanya sejumlah lima tim $(23,80 \%)$ dari total 21 tim dan pada tahun 2011 tim yang sukses menjalankan usahanya 16 tim $(51,61 \%)$ dari total 31 tim (POKJA dalam Wiryani, 2013). Kegagalan dari usaha tersebut diduga dikarenakan sikap yang kurang sungguh-sungguh dalam berusaha dan mengenali potensi diri yang ada dalam diri mahasiswa. Kecenderungan mahasiswa membuat PMW diawali dengan adanya orientasi memperoleh modal bukan sebagai perwujudan pengembangan potensi yang ada dalam diri mahasiswa, sehingga apa yang dikerjakan kurang maksimal. Seharusnya sikap yang kurang sungguh-sungguh tersebut telah terkikis sejak awal, karena sebelumnya peserta telah diberikan pengetahuan awal mengenai motivasi berwirausaha, bisnis, manajemen keuangan, pemasaran, dan lain-lain melalui mata kuliah kewirausahaan.

\section{METODE}

Dilihat dari pendekatannya, penelitian ini menggunakan pendekatan empirik (ex-post facto) yang merupakan suatu penelitian yang dilakukan untuk

Jurnal IImu Sosial dan Humaniora |653 
meneliti peristiwa yang telah terjadi dan kemudian menurut ke belakang untuk mengetahui faktor-faktor yang dapat menimbulkan kejadian tersebut (Sugiyono, 2005). Potensi diri wirausaha mahasiswa yang memfokuskan perhatian pada enam aspek yaitu: kepribadian, disiplin diri, kreativitas, dorongan/keinginan, keberanian menghadapi resiko, dan kepercayaan diri.

Penilaian potensi diri melalui beberapa tahap dengan menempuh langkah-langkah sebagai berikut.

1) Menentukan jumlah skor dari masing - masing aspek yang diperoleh dari data tabulasi yang telah dilakukan terhadap hasil penyebaran kuesioner

2) Menjumlahkan nilai dari masing masing aspek secara total.

3) Menterjemahkan nilai total yang diperoleh ke dalam pengkategorian potensi diri wirausaha.

4) Menganalisis dan menginterpretasikan hasil pengolahan data untuk selanjutnya dideskripsikan.

5) Pengambilan kesimpulan.

\section{HASIL DAN PEMBAHASAN}

\section{Program Mahasiswa Wirausaha} (PMW)

PMW merupakan salah satu program dalam sistem pembelajaran/pendidikan yang ada di perguruan tinggi. Dengan demikian, PMW harus terintegrasi dan disinergikan dengan program-program kewirausahaan yang telah ada seperti: Kuliah Kewirausahan, Program Kreativitas Mahasiswa Kewirausahaan (PKMK), Program Magang/ Belajar Bekerja Terpadu/ Co-op, Kuliah Kerja
Usaha (KKU) dan program kewirausahaan lainnya.

Kewirausahaan dimaknai sebagai semangat, sikap dan perilaku atau kemampuan seseorang dalam melihat peluang, menangani usaha dan atau kegiatan yang mengarah pada upaya mencari, menciptakan, menerapkan cara kerja, teknologi dan produk baru dengan meningkatkan efisiensi dalam rangka memberikan pelayanan yang lebih baik dan atau memperoleh keuntungan yang lebih besar. Kewirausahaan juga merupakan suatu proses kreativitas dan inovasi yang mempunyai risiko tinggi untuk menghasilkan nilai tambah bagi produk yang bermanfaat bagi masyarakat dan mendatangkan kemakmuran bagi wirausahawan. Kewirausahaan itu dapat dipelajari walaupun ada juga orangorang tertentu yang mempunyai bakat dalam hal kewirausahaan. Strategi pendidikan yang diwujudkan dalam PMW bertujuan untuk (1) membangun softskill atau karakter wirausaha; (2) menumbuh kembangkan wirausahawirausaha baru yang berpendidikan tinggi dan memiliki pola pikir pencipta lapangan kerja; (3) mendorong pertumbuhan, perkembangan atau terbentuknya kelembagaan (unit/pusat) pengelola program kewirausahaan di perguruan tinggi; dan (4) mendorong terbentuknya model pendidikan atau pembelajaran kewirausahaan di perguruan tinggi.

\section{Penilaian Potensi Diri Wirausaha}

Banyak orang mengartikan kesuksesan itu dengan ukuran materi. Namun kesuksesan yang sebenarnya adalah kemampuan diri kita untuk mengenali potensi yang terdapat dalam 
diri kita sendiri dan memaksimalkannya menjadi sebuah kompetensi, dan kompetensi tersebut digunakan untuk meraih sesuatu yang lebih baik. Jika potensi yang ada dalam diri kita adalah menjadi seorang pengusaha maka kita harus memaksimalkan potensi kita tersebut. Sebagai langkah awal, mahasiswa wirausaha perlu mengenali perilaku, sikap, dan sistem nilai yang membentuk keseluruhan kepribadian. Di samping kepribadian, kemampuan diri perlu dikenali. Kemampuan ditentukan terutama oleh pengetahuan dan keterampilan. Pengetahuan yang sebaiknya dimiliki oleh mahasiswa wirausaha yaitu intinya kenali diri sendiri, lingkungan, bidang usaha yang dimasuki, tahu apa yang harus dilakukan, dan mengenal proses dan sistem yang ditangani, apa yang dicapai, bagaimana cara mencapainya, dan risiko, serta cara menanggulangi risiko ini. Dengan kata lain, seorang mahasiswa wirausaha perlu memiliki pengetahuan yang cukup untuk dapat mengarahkan dirinya, memperoleh peluang usaha, menyusun konsep usaha, membuat perencanaan, masuk pasar, beroperasi (dalam organisasi/sendiri), dan dengan demikian menikmati nilai tambah dan mengembangkan diri. Keterampilan yang harus dimiliki oleh seorang mahasiswa wirausaha:

1) mempunyai keterampilan konseptual dalam mengatur strategi dan memperhitungkan risiko;

2) mempunyai keterampilan memimpin dan mengelola;

3) mempunyai keterampilan teknis bidang usaha;

4) mempunyai keterampilan berkomunikasi dan berinteraksi, dan
5) mempunyai keterampilan kreatif menciptakan nilai tambah.

Keterampilan tidak hanya untuk diketahui, tetapi juga diperlukan pelatihan yang memadai guna mengembangkan dan mempertajam keterampilan yang kita miliki. Untuk melakukan wirausaha, kita perlu mengadakan penilaian terhadap diri sendiri dan dari luar diri kita, yang akan menentukan keberhasilan dan kegagalan usaha kita. Menurut Suryana (2011) penilaian potensi diri wirausaha dapat dilihat dari enam aspek yaitu aspek kepribadian, disiplin diri, kreativitas, dorongan/ keinginan, keberanian menghadapi risiko, dan kepercayaan diri.

1) Kepribadian, merupakan keseluruhan kualitas psikis diwarisi atau diperoleh yang khas pada seseorang yang membuatnya unik. Dengan kepribadian yang dimiliki oleh seseorang dia dapat memikat orang lain, orang menjadi simpati padanya, orang tertarik dengan pembicaraannya, oang terkesima olehnya. Wirausaha yang memiliki kepribadian seperti ini seringkali berhasil dalam menjalankan usahanya.

2) Disiplin diri, adalah ketepatan komitmen wirausahawan terhadap tugas dan pekerjaannya. Ketepatan yang dimaksud bersifat menyeluruh, yaitu ketepatan terhadap waktu, kualitas pekerjaan, sistem kerja dan sebagainya. Ketepatan terhadap waktu, dapat dibina dalam diri seseorang dengan berusaha menyelesaikan pekerjaan sesuai dengan waktu yang direncanakan.

3) Kreativitas, adalah kemampuan untuk membuat kombinasi-kombinasi baru

Jurnal IImu Sosial dan Humaniora |655 
atau melihat hubungan-hubungan baru antara unsur, data, variabel yang sudah ada sebelumnya.

4) Dorongan/Keinginan berwirausaha dapat datang dari teman sepergaulan, lingkungan keluarga, sahabat di mana mereka dapat berdiskusi tentang ide wirausaha masalah yang dihadapi dan caracara mengatasi masalahnya.

5) Keberanian menghadapi risiko itu ada bilamana waktu yang akan datang (future) tidak diketahui (unknown). Jadi, dengan perkataan lain risiko itu ada bila ada ketidakpastian (uncertainty).

6) Kepercayaan diri, orang yang tinggi percaya dirinya adalah orang yang sudah matang jasmani dan rohaninya. Pribadi semacam ini adalah pribadi yang independen. Karakteristik kematangan seseorang adalah ia tidak tergantung pada orang lain, dia memiliki rasa tanggung jawab yang tinggi, objektif dan kritis.

Secara sederhana dapat dijabarkan penilaian potensi diri wirausaha dalam tabel berikut.

Tabel 1 Penjabaran PenilaianPotensi Diri Wirausaha

\begin{tabular}{|c|c|c|}
\hline No. & Dimensi & Butir Pernyataan \\
\hline \multirow{9}{*}{1.} & \multirow{9}{*}{ Kepribadian } & Suka memberontak \\
\hline & & Sikap keras kepala \\
\hline & & Mempunyai inisiatif (prakarsa) \\
\hline & & Senang menyendiri \\
\hline & & Keinginan untuk menjadi pemimpin \\
\hline & & Bertanggung jawab \\
\hline & & Yakin pada diri, tidak suka memohon bantuan \\
\hline & & Senang mendapat pengawasan \\
\hline & & Menghendaki kebebasan pribadi \\
\hline \multirow{8}{*}{2.} & \multirow{8}{*}{ Disiplin diri } & Bersikap kukuh \\
\hline & & Bertanggung jawab dengan tugas \\
\hline & & Disiplin waktu \\
\hline & & Berani berkorban untuk pekerjaan \\
\hline & & $\begin{array}{l}\text { Memaksakan diri untuk sesuatu yang tidak } \\
\text { disukai }\end{array}$ \\
\hline & & Konsentrasi dalam mengerjakan sesuatu \\
\hline & & Mau belajar dari kesalahan \\
\hline & & Dorongan pribadi yang kuat untuk maju \\
\hline \multirow{5}{*}{3.} & \multirow{5}{*}{ Kreatifitas } & Banyak inisiatif untuk menyelesaikan masalah \\
\hline & & Menggap masalah sebagai tantangan \\
\hline & & Mempunyai ide-ide baru \\
\hline & & Pandai menyesuaikan diri \\
\hline & & Mempunyai rasa ingin tahu \\
\hline
\end{tabular}




\begin{tabular}{|c|c|c|}
\hline No. & Dimensi & Butir Pernyataan \\
\hline & & Bersifat intuitif \\
\hline & & Bersikap terbuka pada hal-hal yang baru \\
\hline & & Mempunyai imajinasi yang tinggi \\
\hline & & $\begin{array}{l}\text { Menggunakan cara-cara baru dalam melakukan } \\
\text { sesuatu }\end{array}$ \\
\hline \multirow{10}{*}{4.} & \multirow{10}{*}{ Dorongan } & $\begin{array}{l}\text { Mempunyai dorongan tinggi untuk melakukan } \\
\text { sesuatu }\end{array}$ \\
\hline & & $\begin{array}{l}\text { Keinginan yang teguh untuk mengerjakan } \\
\text { sesuatu }\end{array}$ \\
\hline & & $\begin{array}{l}\text { Bersedia berkorban untuk mewujudkan } \\
\text { keinginan }\end{array}$ \\
\hline & & Memiliki keberanian \\
\hline & & Tepat hati \\
\hline & & Penuh niat \\
\hline & & Kukuh \\
\hline & & Positif \\
\hline & & Tepat janji \\
\hline & & Penuh ambisi \\
\hline \multirow{7}{*}{5.} & \multirow{7}{*}{$\begin{array}{c}\text { Keberanian } \\
\text { menghadapi resiko }\end{array}$} & Berani mengambil resiko \\
\hline & & Suka pada tantangan \\
\hline & & Memanfaatkan kesempatan dengan baik \\
\hline & & $\begin{array}{l}\text { Keyakinan yang tinggi terhadap apa yang telah } \\
\text { dilakukan }\end{array}$ \\
\hline & & Berani berspekulasi \\
\hline & & Tidak gentar dengan kegagalan \\
\hline & & Berani mencoba suatu hal baru \\
\hline \multirow{5}{*}{6.} & \multirow{5}{*}{ Kepercayaan diri } & Keteguhan \\
\hline & & Ketidak tergantungan \\
\hline & & Kepribadian mantap \\
\hline & & Optimisme \\
\hline & & Percaya pada diri sendiri \\
\hline
\end{tabular}

Sumber: diadaptasi dari Suryana, 2011 dan Alma, 2005

3. Pentingnya Penilaian Potensi Diri sebagai Pondasi untuk Mensukseskan Mahasiswa Wirausaha
Kebijakan dan program peningkatan peran yang mendorong penguatan kelembagaan kewirausahaan dalam bentuk PMW timbul didasari atas pemikiran 
meningkatkan kualitas pembelajaran dan aktivitas berwirausaha dan percepatan pertumbuhan wirausahawirausaha baru dengan basis Ipteks sangat diperlukan. PMW sebagai bagian dari strategi pendidikan kewirausahaan di perguruan tinggi, dimaksudkan untuk memfasilitasi para mahasiswa yang mempunyai minat berwirausaha dan memulai usaha dengan basis ilmu pengetahuan, teknologi dan seni. Hanya saja, jarang ditemukan seseorang sarjana yang ingin mengawali kehidupannya setelah lulus dari perguruan tinggi dengan berwirausaha.

Kegagalan dari usaha tersebut diduga dikarenakan sikap yang kurang sungguh-sungguh dalam berusaha dan mengenali potensi diri yang ada dalam diri mahasiswa. Kecenderungan mahasiswa membuat PMW diawali dengan adanya orientasi memperoleh uang bukan sebagai perwujudan pengembangan potensi yang ada dalam diri mahasiswa, sehingga apa yang dikerjakan kurang maksimal.

Penilaian potensi diri wirausaha yang dimiliki oleh seorang mahasiswa dapat dinilai dengan pedoman skor perolehan dari penjabaran masingmasing dimensi Tabel 1 yang dalam pengkategoriannya adalah seperti Tabel 2 berikut.

Tabel 2 Kategori Penskoran Penilaian Potensi Diri Wirausaha

\begin{tabular}{|c|c|}
\hline $\begin{array}{c}\text { Nilai Potensi } \\
\text { Diri }\end{array}$ & Kategori \\
\hline $320-360$ & $\begin{array}{l}\text { Anda seorang yang mandiri, penuh semangat dengan dorongan } \\
\text { dan ketertiban (disiplin) yang dibutuhkan oleh seorang } \\
\text { wirausahawan yang berhasil ketika anda mengambil suatu } \\
\text { keputusan untuk melakukan sesuatu hal, anda akan dapat } \\
\text { menyelesaikan pekerjaan itu. Jika anda memutuskan untuk } \\
\text { berwiraswasta, anda mempunyai cirri-ciri kepribadian untuk } \\
\text { berhasil. }\end{array}$ \\
\hline $280-319$ & $\begin{array}{l}\text { Anda memiliki banyak hal positif untuk dapat berhasil dalam usaha } \\
\text { anda sendiri, tetapi tidaklah berarti anda dapat segera } \\
\text { mengundurkan diri dari pekerjaan anda saat ini hanya dikarenakan } \\
\text { niat anda yang tinggi dalam tes. }\end{array}$ \\
\hline $210-279$ & $\begin{array}{l}\text { Anda memiliki potensi kerja. Berusahalah untuk mengembangkan } \\
\text { diri anda. Banyak-banyaklah, ikutilah pelajaran-pelajaran dan } \\
\text { bergaulah dengan para wiraswastawan yang berhasil guna } \\
\text { mengetahui apa saja yang mereka lakukan. }\end{array}$ \\
\hline $120-209$ & $\begin{array}{l}\text { Jalankan terus cara kehidupan anda saat ini dengan hati-hati. } \\
\text { Anda membutuhkan banyak dorongan, ketertiban diri dan } \\
\text { kepercayaan dalam usaha anda sendiri pada tahap ini. Anggaplah } \\
\text { nilai rendah anda dalam tes sebagai suatu tantangan untuk } \\
\text { memperkuat ciri-cirikepribadian yang penting yang akan anda } \\
\text { butuhkan dalam berwiraswasta agar berhasil. }\end{array}$ \\
\hline $1-119$ & Sampai anda dapat mengembangkan kreativitas, kemampuan \\
\hline
\end{tabular}




\section{Nilai Potensi Diri}

\section{Kategori}

menghadapi resiko dan kepercayaan anda dan meningkatkan dorongan dan disiplin diri sendiri, anda barang kali baru tepat untuk berhenti bekerja dari orang lain.

Sedikit tidaknya dengan mengenali potensi diri yang ada dalam diri mahasiswa dapat memberikan gambaran tentang seberapa jauh seseorang tersebut merasa dirinya perlu memperbaiki diri dan belajar agar lebih baik lagi. Mengenal diri sendiri berarti memperoleh pengetahuan tentang totalitas diri yang tepat, yaitu menyadari kelebihan/ keunggulan yang dimiliki maupun kekurangan/ kelemahan yang ada pada diri sendiri yang nantinya menjadi sumber kesuksesan dalam berwirausaha. Ada sepuluh hal yang harus dimiliki dan selalu diingat oleh seorang wirausaha sukses yaitu: (1) Find your purpose and Dream all the time, yaitu sukses dalam sebuah perjalanan bukan tujuan; (2) Neverending Innovation, yaitu inovasi tiada henti; (3)Learn-Cchange and Grow: Senantiasa belajar, belajar, dan belajar; (4) Accomulative your asset: tujuan akhir wirausaha adalah mencapai keberhasilan financial; (5) Use Leverage concept to build your business: seseorang wirausaha yang cerdas harus mampu menggunakan tenaga dan waktu orang lain untuk mencapai tujuannya; (6) Nature Equep Develop your people: mampu menggunakan tenaga dan waktu orang lain untuk mencapai tujuannya; (7) Systemize your business: mampu membangun sistem bisnis yang efektif dan efisien; (8) Build network and alliance: mampu membuat jaringan kerja yang kuat baik dalam segi peluang bisnis, modal, maupun akses pada pemerintah; (9) Be Smart investor: salah satu kekuatan wirausaha yang cerdas dan sukses adalah kemampuan dalam mengelola portopolio asetnya sehingga senantiasa berkembang dan bertambah banyak; (10) The Power of Giving: Give and be Grateful: kebiasaan wirausaha sejati adalah beramal dan mengucapkan syukur.

\section{PENUTUP}

Pengetahuan yang sebaiknya dimiliki oleh wirausahawan yaitu intinya kenali diri sendiri, lingkungan, bidang usaha yang dimasuki, tahu apa yang harus dilakukan, dan mengenal proses dan sistem yang ditangani, apa yang dicapai, bagaimana cara mencapainya, dan resiko, serta cara menanggulangi risiko ini. Dengan kata lain, seorang wirausaha perlu memiliki pengetahuan dan keterampilan yang cukup untuk dapat mengarahkan dirinya, memperoleh peluang usaha, menyusun konsep usaha, membuat perencanaan, masuk pasar dan beroperasi dalam (organisasi/ sendiri).

Keterampilan tidak hanya untuk diketahui, tetapi juga diperlukan pelatihan yang memadai guna mengembangkan dan mempertajam keterampilan yang kita miliki. Untuk melakukan wirausaha, kita perlu mengadakan penilaian terhadap diri 
sendiri dan dari luar diri kita, yang akan menentukan keberhasilan dan kegagalan usaha kita.

\section{DAFTAR PUSTAKA}

Alma, Buchari. Kewirausahaan Untuk Mahasiswa dan Umum. Edisi Revisi. Bandung: Alfabeta.

Anonim. 2013. Kewirausahaan Modul Pembelajaran. Direktorat Pembelajaran dan Kemahasiswaan Ditjen Pendidikan Tinggi Kementerian
Pendidikan dan Kebudayaan. Jakarta.

Anonim.2015. Panduan Program Mahasiswa Wirausaha. Tersedia pada http://dikti.kemdiknas.go.id

Soegoto, Eddy. 2009. Entrepreneurship Menjadi Pembisnis Ulung. Elex Media Computindo.

Suryana, Yuyus. 2011. Kewirausahaan Pendekatan Karaktersitik Wirausahaan Sukses. Jakarta: Kencana Prenada Media Group. 